\title{
Mobile Apps Based on Keller Personalized System of Instruction to Promote English Vocabulary Acquisition
}

\author{
https://doi.org/10.3991/ijim.v15i23.27227 \\ Rooban Arumugam ${ }^{1(\mathbb{凶})}$, Norah Md Noor ${ }^{2}$ \\ ${ }^{1}$ Sekolah Kebangsaan Seri Saujana, Kota Tinggi Johor, Malaysia \\ ${ }^{2}$ University Teknologi Malaysia, Johor, Malaysia \\ rooban. arumugam@gmail.com
}

\begin{abstract}
Mobile learning (or m-learning) is the ability to learn anywhere and at any time using a portable electronic device. Mobile technologies gradually integrate into learnedness. Mobile devices and apps are changing the way learners acquires English. This study aims to develop a mobile Apps based on the Keller Plan Personalized system of instruction (PSI) theory called JuJu English Vocabulary to improve learners' vocabulary acquisition. The mobile Apps was developed using ADDIE instructional design model. The developed Apps was investigated using a quasi-experimental research design among 60 students separated into two(2) groups: control and experimental groups. Data were analysed using SPSS software. The outcome shows a significant difference between Post-test experimental (using the mobile app) and the control group (traditional learning). This Mobile Apps design allows personalised growth among the experimental group of students in terms of their vocabulary acquisition. The design mimicking a game strategy did help increase their interest to enjoy the learning process.
\end{abstract}

Keywords—English vocabulary, mobile apps, mobile learning, Keller personalized system of instruction

\section{$1 \quad$ Introduction}

In Malaysia, the English curriculum has undergone a new revolution in 2018 known as the KSSR syllabus. Administrated by the Ministry of Education, the Common European Framework of Reference for Languages (CEFR) used for describing language degrees has been in use in every school since this January [8]. This initiative is one stride forward brought by the Ministry of Education Malaysia to improve students' English knowledge. In line with the government's objective in strengthening English, the curriculum design serves pupils efficiently in the language. The direction of the English language syllabus is to aid pupils to develop the language in a term to help them it in their daily lives, their studies and employment prospects in the future.

At the moment, the English language is the most utilised international language. Knowing English as a spoken and written language is one of the most critical acquirements that we can have in today's interconnected humankind. It enhances our teaching to increase your value in each working sector. English language considers 
one of the most important languages of the world. It is widely spoken across the globe, even on the internet. Mastery English vocabulary represents one of the most important attainments necessary for teaching and learning a foreign language. It is the basis for developing all the other skills such as reading inclusion, listening comprehension, speaking, writing, spelling, and pronunciation.

The monetary standard based English linguistic process curriculum for Malaysia national primary school is designed to prove pupils with a strong cornerstone in English nomenclature. Teachers should use standard British English as an address and model for teaching the language. It should be used as a reference for spelling and grammar as well as the pronunciation for standardisation [11].

In the Malaysian context, the primary coil of education is divided into two stages: stage one referring to year 1, 2 and 3 and stage two referring to year 4, 5 and 6 . In years 1 and 2, the English language program emphasises the development of basic language accomplishment to have a strong foundation to build their proficiency in the language. In order to shuffle learning more meaningful and purposeful, language input is presented under themes and topics which are appropriated for pupils. Three broad themes have been identified in the program which is World and Self, Family and Friends, World of Stories and World of Knowledge.

\section{Literature review}

The implementation of CEFR and the introduction of the SuperMind Cambridge textbooks came with the hopes of helping pupils to achieve native-like fluency and accuracy in their English proficiency. It comes in line with the needs of Shift 2 in the National Educational Blueprint that highlights the importance of proficiency of languages learnt, be it Bahasa Malaysia or English. These materials are introduced as an exposure tool of the target language [8].

There is, however, a glitch in this implementation. The bane of CEFR is its source material, the Super Minds Cambridge Textbook. The textbook is not set in the context of Malaysian cultures and norms instead of previous English textbooks [11]. The textbook which is a paragon of Cambridge English is set in the western context. Though learners in Malaysia are considered ESL learners, with the Super Mind textbook, learners are introduced to foreign concepts and lexicons that they could not relate to. During the lower primary level, learners build on their vocabulary repertoire that will eventually help them in their upper primary where they have to face ministry sanctioned assessments such as UPSR.

Vocabulary is the building blocks of learning English. It is not far-fetched to say that vocabulary is the foundation that cements the capacity of communication. In the moment or foreign choice of word information in disparate, vocabulary plays a pertinent role in devoting oneself to the precondition for communication. The use of the Super Minds textbook introduces learners to vocabularies that are arguably quite foreign [11]. As the medium of dissemination, teachers feel the mounting pressure to explore ways to facilitate the learning process.

The conventional chalk and talk and vocabulary drills no longer accommodate the learning of today's learners. Learners of this age are what we would call digital natives 
and methods of teaching them has to transcend the limitations of the blackboard. And this is where technology makes its mark.

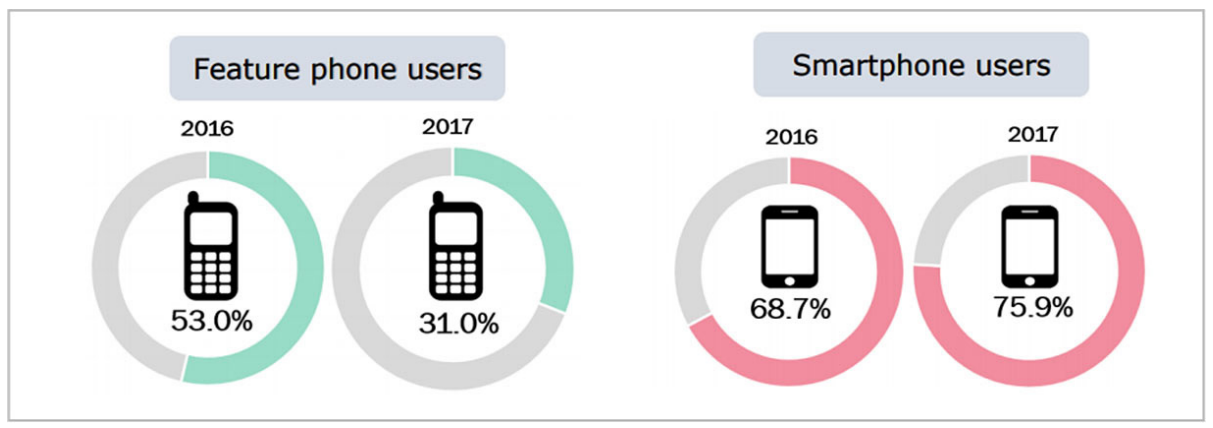

Fig. 1. Percentage distributions of smartphones versus feature phone share (Malaysian Communications and Multimedia Commission, 2017)

According to the statistics from the Malaysian Communications and Multimedia Commission, there is a steady increase of mobile phone users, namely the users of smartphones. As illustrated in Figure 1, in the year 2017, 75.9\% of mobile phone users use smartphones as opposed to feature phones. Feature phones are mobile phones that offer the basic needs of communication such as making phone calls, texting and other functions without the benefit of wireless internet connection. Smart phones are phones that boast a wide array of functions, including the benefit of wireless internet connection.

Versatile devices that could be used in many facets of our life and it is high time that mobile devices are incorporated in the education sector. There are many ways that mobile devices could be implemented in the classroom as demonstrated below (see Figure 2).

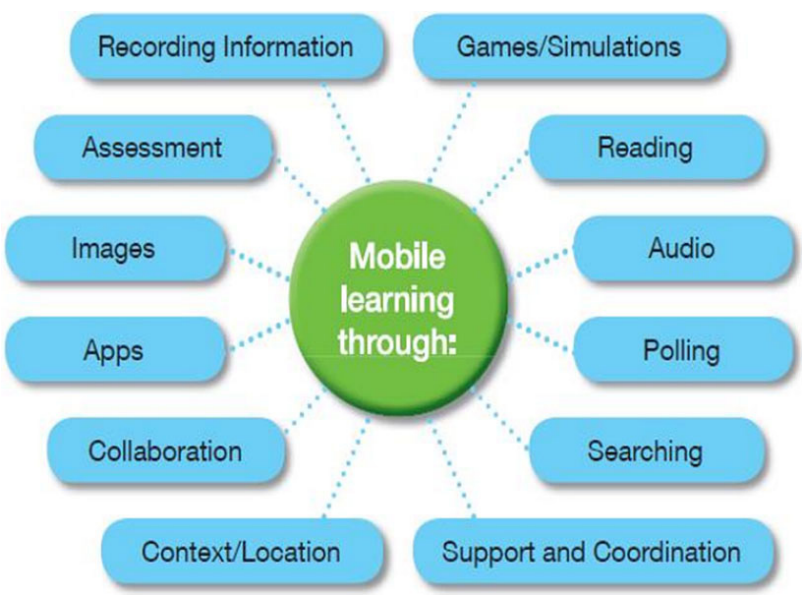

Fig. 2. The use of mobile phone in learning 
According to [14], using a Mobile device in learning can help to improve students motivation, encourage responsibility toward studies, promote collaborative learning, especially in the group task, and helps check student's progress faster more efficiently. The process of pedagogy and learning is now no longer concentrated interior the classroom only but also can happen anywhere and whenever. The education organisation has undergone another evolution in technology education when mobile learning or Mobile Learning (M-Learning) was introduced to improve the level of teaching methods and learning the ability. In Malaysia, M-Learning is ongoing research to perfecting the implementation to ensure that learning is not bound to any physical location [4]. Learning in Mobile has proven its effectiveness in foreign countries ([2], [12], [15], [19]). Sharing among students can be easily facilitated with the availability of mobile devices, and they do not have to sit in front of personal computers to download pre-eminence.

Computer Assisted Language Learning (CALL) has long made its appearance in the teaching of vocabulary. [18] found that students in the treatment group studied using CALL showed significantly better vocabulary, reading comprehension, and a decrease in reaction time for frequent word recognition. Considering a large amount of vocabulary that L2 learners need to learn and develop, and positive influence towards student vocabulary learning the integration of CALL is increasingly seen as an attractive option for learning ([7], [9], [13]). The features in CALL include video, music, animations, and graphics help the students learn better.

In the veins of CALL, Mobile Assisted Learning Language (MALL) is gaining traction in the world of English methodology. The rapid change in numerous mobile devices, such as the smartphone display, has shifted how we understand learning. The ubiquity of mobile devices possibly supports student access to learning materials anytime and anywhere, leading to increased connection with formal and informal learning [5].

Mobile applications are the latest technological developments to come through in English language learning. A number of researchers have studied the pedagogical possibilities of mobile phones for basic English language learning and vocabulary learning. The findings either shows a significant improvement because of using the MALL ([2], [12], [15]) or just positively shows user preference towards using it for learning ([16], [17], [19]).

With the proven benefits of mobile learning and the problems that have arisen with the implementation of CEFR in teaching English, it is a prudent step to tackle the problem with this interactive methodology. However, there is an issue that students are having difficulties when learning in a personalised learning environment through the web or mobile learning. Due to that, a proper Personalised Learning model or strategy should be adapted when developing Mobile Learning for teaching English. [6] found that their Keller's Personalized System of Instruction (PSI) students ended the semester with higher final examination scores than lecture students; the difference was better for the lowest GPA group. Low aptitude PSI students showed increases in learning goals over time when compared to low aptitude lecture students. So, a proper mobile learning application based on Keller's Personalized System of Instruction (PSI) should be developed to help students learn English Vocabulary. 


\section{$3 \quad$ Research objectives}

The objectives of this research are to:

i) To develop a mobile Apps based on Keller Plan (Personalised system of instruction theory to improve learners' vocabulary acquisition.

ii) To investigate the effectiveness of the developed mobile application in the teaching of vocabulary.

iii) To investigate the perceptions of learners towards the use of mobile applications in the classroom.

\section{$4 \quad$ Methods}

In order to investigate the effectiveness of the developed mobile app in the teaching of vocabulary, the researcher has decided to employ the Quasi-Experimental Research design using pre-test / post-test as a data collection method as it allows the researcher to gather information efficiently. Whereas, to investigate learners' perceptions of mobile applications in the classroom, the researcher used a questionnaire as a data collection instrument.

To check the reliability of the instruments, Cronbach Alpha Coefficient was used to test all the scales in the study. Inferential analysis was used to answer research question 1. Meanwhile, descriptive analysis of mean, frequency and percentage was used to analyse the raw data gathered to answer research question 2 and research question 3.

The research mainly focalises on the learners of primary schoolings learners at the age of 8 who attend year 2 at one school in south Malaysia and the researcher has chosen two classes for this research. The researcher chose two classes that did not perform well in the English monthly assessment. Researcher split the classes into two different group. The first group was the treatment group and while the other was the control group. The total of learners chosen are 60 .

\section{$5 \quad$ Design of the mobile apps}

The JuJu Vocabulary is an android version of the application. It is developed by using AI2 MIT website. The application content many user-defined activities. JuJu Vocabulary application developed based on year 2 English syllabus (Super Mind Book). Keller Personalized Model of Instruction was used in the process of designing the application. Each of the topics is made as modules. User (student) need to learn and practice each module completely before proceeding to the next module. Figures below (see Figures 3, 4 and 5) show the illustrates flow of the application. 


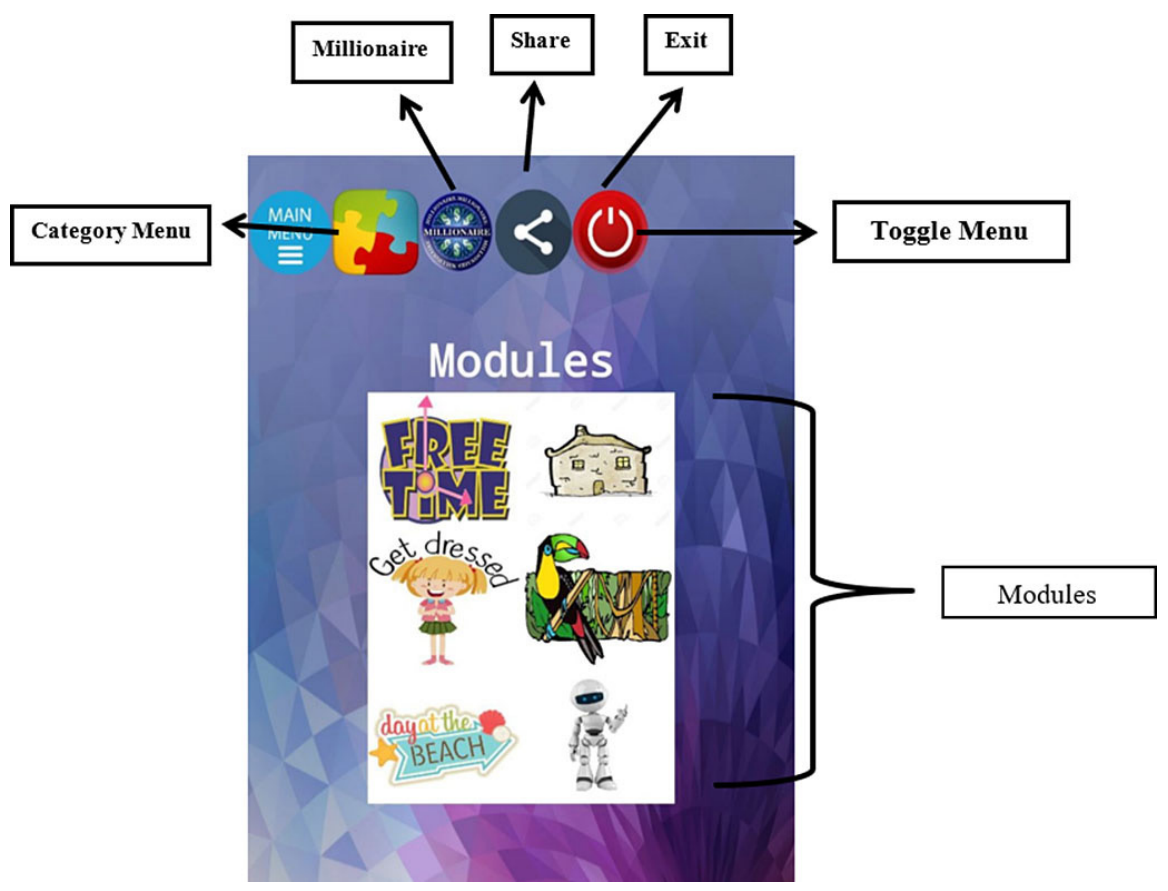

Fig. 3. Main menu showing 6 modules in the JuJu mobile apps

Learners will start from the first module. If they can perform well in answering tests for that module, they can unlock the next module. 6 modules are available. Learners need to complete 6 modules before proceeding to Millionaire game. The millionaire game content questions based on the 6 modules. Millionaire game designed with timing. Learners need to finish the game before the timing. Share button to share the application to others. 


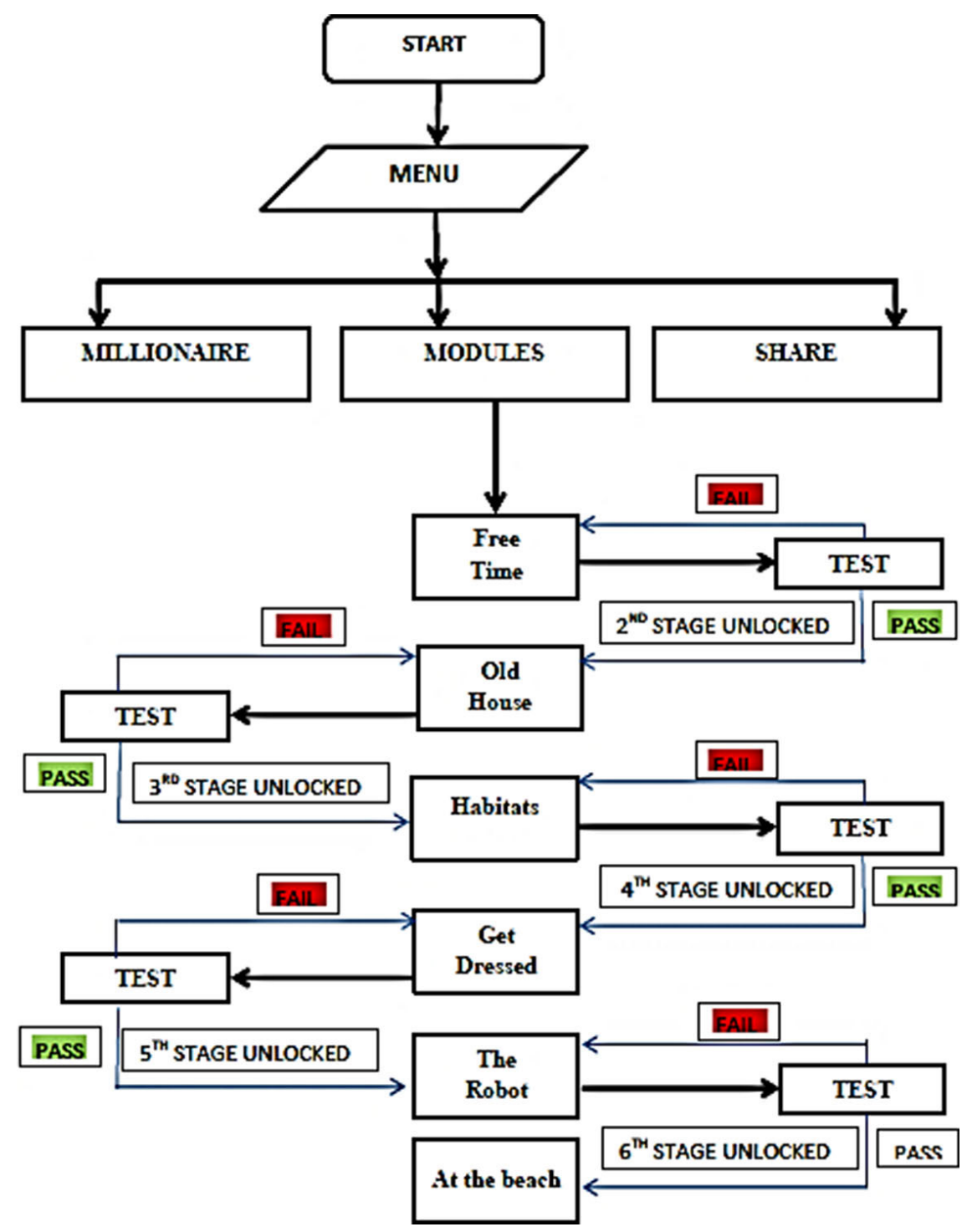

Fig. 4. Flowchart of the mobile apps design 

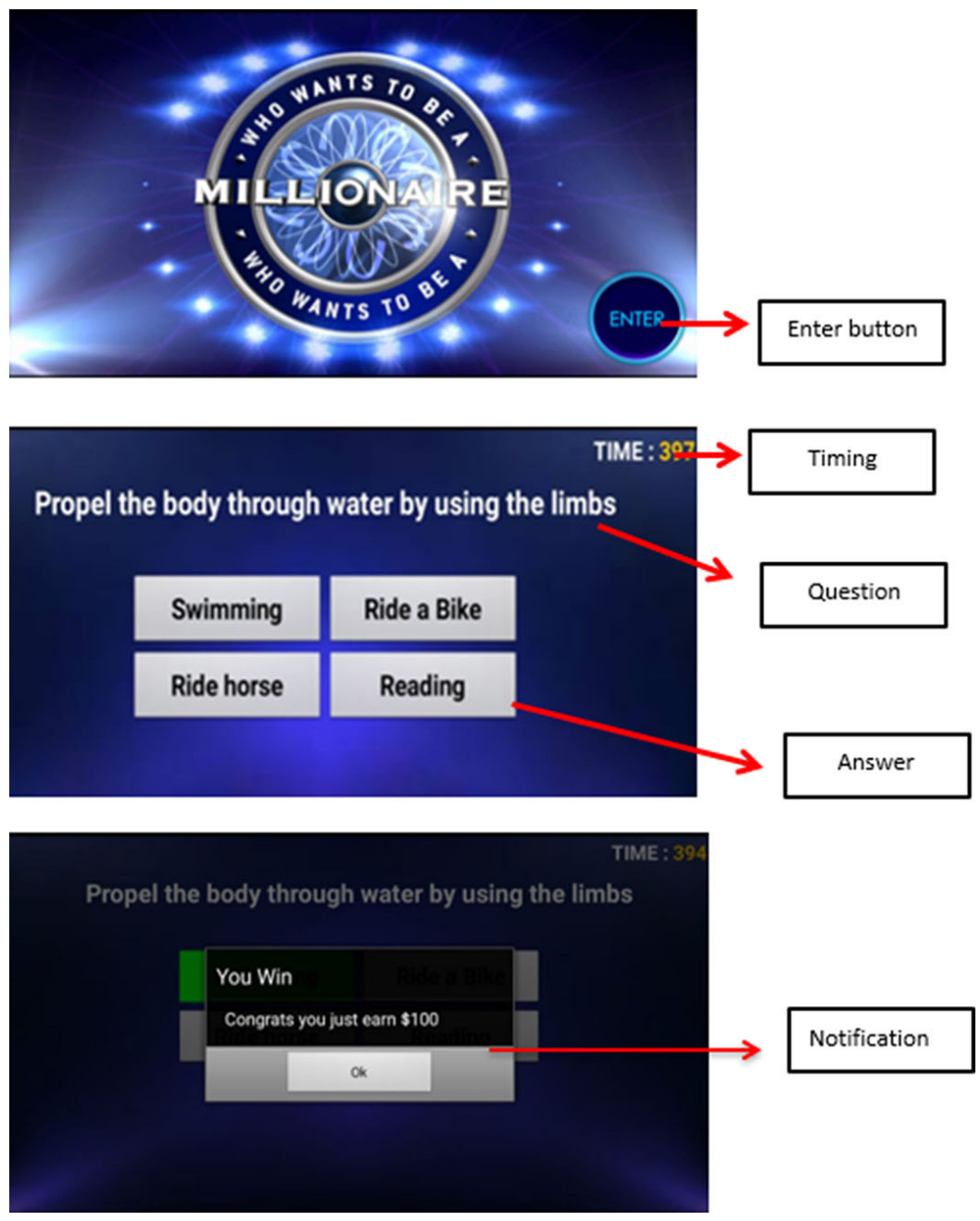

Fig. 5. Screenshot of the millionnaire games in JuJu apps

\section{Data analysis and discussion}

\subsection{Effectiveness of the developed mobile application in the teaching of vocabulary}

Results of the experiment consist of two parts. This first part is the results of the pretest. The second part is the results of the post-test. There were 60 participants $(\mathrm{n}=60)$. 30 participants set as control group and 30 participate experimental group. The Control group was taught with traditional activities whereas the experimental group was taught with the use of mobile application. 
Pre-test consisting of 40 questions was used as data collection tool. Each question that answered correctly in the test will be given 2.5 points $(40 \times 2.5$ points $=100 \%)$. The test includes 20 objective and 20 subjective questions. The two groups were tested with their knowledge by 40 questions. Based on the pre-test result, there were no significant differences between two groups, which means their knowledge level is similar. The next day the learning process start with introducing JuJu Vocabulary application to experimental group. All of the learners install the application, and the teacher will guide them in learning vocabulary. While the control group will learn using printed material and including traditional learning strategy.

Once finish modules and fulfill the test in the mobile application the experimental group will play millionaire game without any guidance's. Teacher gave reward to the kids that score highest. The treatment took 4 weeks' time. After both groups finished their 6 modules they given a test based on the modules. The test results were used as post-test. The scores were analysed using descriptive analysis as shown in Table 1.

Table 1. Descriptive statistic of pre-test and post-test of experimental and control group

\begin{tabular}{|l|c|c|c|c|c|}
\hline & N & Minimum & Maximum & Mean & Std. Deviation \\
\hline pretest_ex & 30 & 40 & 76 & 57.73 & 10.329 \\
\hline posttest_ex & 30 & 70 & 96 & 83.93 & 6.777 \\
\hline pretest_con & 30 & 40 & 72 & 54.87 & 9.183 \\
\hline posttest_con & 30 & 46 & 80 & 62.13 & 9.217 \\
\hline Valid N (listwise) & 30 & & & & \\
\hline
\end{tabular}

Normality test applied which will be used to make firm in the analysis of the data in this research whether the data is normally distributed. In the case, results of test the data suitable normal distribution should be $(\mathrm{p}>0.05)$.

The hypotheses of the researcher for testing normality are:

a. $\mathrm{H}_{0}$ : Data is in normal distribution

b. $\mathrm{H}_{1}$ : Data is not in normal distribution.

$\mathrm{H}_{0}$ is rejected when the significance value is: lower than $0.05(\alpha=5 \%)$.

Table 2. Tests of normality

\begin{tabular}{|l|l|c|c|c|c|c|c|}
\hline \multirow{2}{*}{ Class } & \multicolumn{2}{|c|}{ Kolmogorov-Smirnov } & \multicolumn{3}{c|}{ Shapiro-Wilk } \\
\cline { 3 - 8 } & & Statistic & df & Sig. & Statistic & df & Sig. \\
\hline Result_pretest & $\begin{array}{l}\text { Experimental } \\
\text { Group }\end{array}$ & .100 & 30 & $.200^{*}$ & .959 & 30 & .285 \\
\cline { 2 - 8 } & Control Group & .112 & 30 & $.200^{*}$ & .954 & 30 & .219 \\
\hline Result_posttest & $\begin{array}{l}\text { Experimental } \\
\text { Group }\end{array}$ & .153 & 30 & .073 & .958 & 30 & .270 \\
\cline { 2 - 8 } & Control Group & .114 & 30 & $.200^{*}$ & .963 & 30 & .377 \\
\hline
\end{tabular}


Based on Table 2 above, the significance value from pre-test Experimental is 0.285 and from the post test is 0.270 . Both value from pre-test and post-test are bigger than 0.05. It means that $\mathrm{H}_{0}$ is accepted and $\mathrm{H}_{1}$ is rejected, so the data is in normal distribution. While the significance of pre-test of control group 0.219 and Post-test Control group is 0.377 . Both equally more than significance that set before. It also means that $\mathrm{H}_{0}$ is accepted and $\mathrm{H}_{1}$ is rejected, and the data is in normal distribution. So, it can be interpreted that both of data (pre-test and post-test score) are in normal distribution.

Paired Sample T test was used to answer for research question, How effective is the developed mobile application in the teaching of vocabulary?

Table 3. Paired sample t-test

\begin{tabular}{|c|c|c|c|c|c|c|c|c|c|}
\hline \multicolumn{10}{|c|}{ Paired Differences } \\
\hline & & \multirow[t]{2}{*}{ Mean } & \multirow[t]{2}{*}{$\begin{array}{c}\text { Std. } \\
\text { Deviation }\end{array}$} & \multirow[t]{2}{*}{$\begin{array}{l}\text { Std. } \\
\text { Error } \\
\text { Mean }\end{array}$} & \multicolumn{2}{|c|}{$\begin{array}{l}\mathbf{9 5 \%} \text { Confidence } \\
\text { Interval of the } \\
\text { Difference }\end{array}$} & \multirow[t]{2}{*}{$\mathbf{t}$} & \multirow[t]{2}{*}{ df } & \multirow[t]{2}{*}{$\begin{array}{c}\text { Sig. } \\
\text { (2-tailed) }\end{array}$} \\
\hline & & & & & Lower & Upper & & & \\
\hline Pair 1 & $\begin{array}{l}\text { pretest_ex - } \\
\text { posttest_ex }\end{array}$ & -26.200 & 9.026 & 1.648 & -29.571 & -22.829 & -15.898 & 29 & .000 \\
\hline Pair 2 & $\begin{array}{l}\text { pretest_con- } \\
\text { posttest_con }\end{array}$ & -7.267 & 4.051 & .740 & -8.779 & -5.754 & -9.825 & 29 & .000 \\
\hline
\end{tabular}

Table 3 shows that there is a different score in using traditional method and after taught using mobile app. Pair 1 having the biggest impact then Pair 2.

Researcher also continue with another test, called Independent T-Test to compare the means between two groups to determine whether there is statistical evidence that the associated population means are significantly different. Table 4 shows the output of Independent T-Test. The calculation based on Post Test Experimental and Post Test Control.

Table 4. Independent samples test

\begin{tabular}{|c|c|c|c|c|c|c|c|c|}
\hline \multirow{2}{*}{\multicolumn{2}{|c|}{$\begin{array}{c}\text { Levene's Test for } \\
\text { Equality of Variances }\end{array}$}} & \multirow{3}{*}{$\frac{\mathbf{F}}{3.570}$} & \multirow{3}{*}{$\begin{array}{l}\text { Sig. } \\
.064\end{array}$} & \multicolumn{5}{|c|}{ t-test for Equality of Means } \\
\hline & & & & \multirow{2}{*}{$\begin{array}{c}\mathbf{t} \\
10.437\end{array}$} & \multirow{2}{*}{$\begin{array}{l}\text { Df } \\
58\end{array}$} & \multirow{2}{*}{$\begin{array}{c}\begin{array}{c}\text { Sig. } \\
\text { (2-tailed) }\end{array} \\
.000\end{array}$} & \multirow{2}{*}{$\begin{array}{c}\begin{array}{c}\text { Mean } \\
\text { Difference }\end{array} \\
21.800\end{array}$} & \multirow{2}{*}{$\begin{array}{c}\begin{array}{l}\text { Std. Error } \\
\text { Difference }\end{array} \\
2.089\end{array}$} \\
\hline Outcome & $\begin{array}{l}\text { Equal } \\
\text { variances } \\
\text { assumed }\end{array}$ & & & & & & & \\
\hline & $\begin{array}{l}\text { Equal } \\
\text { variances } \\
\text { not assumed }\end{array}$ & & & 10.437 & 53.265 & .000 & 21.800 & 2.089 \\
\hline
\end{tabular}

The outcome shows that sig. ( 2 tailed) are $\mathbf{0 . 0 0 0}<\mathbf{0 . 0 5}$ means there are difference between Post-test experimental (using mobile app) and Control group (traditional learning). 
Table 5. Result of descriptive independent samples test

\begin{tabular}{|l|l|c|c|c|c|}
\hline \multicolumn{7}{|c|}{ Group Statistics } \\
\hline \multirow{2}{*}{ Class } & $\mathbf{N}$ & Mean & Std. Deviation & $\begin{array}{c}\text { Std. Error } \\
\text { Mean }\end{array}$ \\
\hline \multirow{2}{*}{ Outcome } & Post test Experimental & 30 & 83.93 & 6.777 & 1.237 \\
\cline { 2 - 6 } & Post test Control & 30 & 62.13 & 9.217 & 1.683 \\
\hline
\end{tabular}

In Table 5, mean of Descriptive Independent Sample shows that Post Test Experimental is more significant than Post Test Control group. It clearly shows that students in the experimental group learning using JuJu Apps perform better than students in the control group learning using conventional method.

\subsection{Perceptions of learners towards the use of mobile applications in the classroom}

Descriptive statistic used to know the perception of students towards the mobile app. Students given a questionnaire form to fill up their feeling for the question that asked in. There are 10 questions that focus on the application. The questionnaire will answer by the students once one their post-test.

Total of 30 students in the experimental group answer the questionnaire. Each item was answered based on three (3) scales: agree, neutral, and disagree. Each scale is represented using a smiley.

The result of the questionnaire has been analysed using descriptive statistics - the output of the analysis given below (see Table 6).

Table 6. Items in the questionnaire

\begin{tabular}{|l|c|c|}
\hline \multicolumn{1}{|c|}{ Items } & \multicolumn{2}{c|}{ Percentage } \\
\cline { 2 - 3 } & Agree & Disagree \\
\hline The application is user friendly. & $100 \%$ & $0 \%$ \\
\hline I am enjoying using the JuJu English Vocabulary application & $100 \%$ & $0 \%$ \\
\hline JuJu English Vocabulary application improved my learning skills & $96 \%$ & $4 \%$ \\
\hline This application has helped me to learn more things I'm interested in & $100 \%$ & $4 \%$ \\
\hline Defining Vocabularies with pictures are helpful. & $100 \%$ & $4 \%$ \\
\hline The content in the application is readable. & $100 \%$ & $4 \%$ \\
\hline The text and pictures are clear and easy to understand. & $96 \%$ & $4 \%$ \\
\hline $\begin{array}{l}\text { JuJu English Vocabulary application improve my learning } \\
\text { performance. }\end{array}$ & $96 \%$ & $4 \%$ \\
\hline English Vocabulary motivated for active participation and discussion & $96 \%$ & \\
\hline $\begin{array}{l}\text { Voice recognition in the English Vocabulary application was very } \\
\text { helpful }\end{array}$ & $96 \%$ & $4 \%$ \\
\hline Valid N (list wise) & & $4 \%$ \\
\hline
\end{tabular}


All the students also shared that they like to learn mobile application-based lesson again even after the duration of the study has come to an end. In general, they have agreed that the lessons are good for them and their eagerness to learn in the future is fuel to educators. The mobile application was accepted by most of the students, and they start to enjoy using it. They can discover each one of the buttons and its functions by their own. Most of the students able to finish and memorise all the words. The learning method suit for the students.

\section{Conclusion}

The JuJu English Vocabulary mobile app developed according to Personalised system of Instruction by Keller. The learning pages contain the vocabulary word, image and audio to help the students to understand better. To complete each module students, need to answer all the questions in Quiz part. If they failed, they would return to the same modules. This will continue till they answer all the quiz correctly. The end of the module's students will be examined with Millionaire game on vocabulary words that students have learn in all the modules.

This study indicates that both the participants in the control group who learn conventionally and the experimental group who had the chances using JuJu English Vocabulary mobile app significantly improved their vocabulary knowledge. However, based on the post-test results, participants in the experimental group who learned vocabulary using the mobile application achieved significantly better than their counterparts in the control group, indicating that use of the mobile application positively effect students learning. This finding is similar with research done by [2], [12] and [15]. Even though [1] reported no significant difference between the experimental and control groups on the post-test, but he found that students attitudes towards the use of mobile applications in teaching vocabulary is positive. [17] also inform in their research that mobile learning benefits led to strong and positive preferences for using mobile devices to self-study English.

In conclusion, this JuJu English Vocabulary mobile app allows personalized growth among the experimental group of students in terms of their vocabulary acquisition. Majority of the students enjoy using it and they like to use it again even after the duration of the study has come to an end. As claimed by [10], each learner's abilities and vocabulary learning needs are unique, students could use an app of their choice in their own designated amount of time.

JuJu English Vocabulary can be used in the classroom or home because it is develop based on Personalized system of Instruction by Keller. Mobile app can help the teachers specifically in providing attractive and engaging lessons without spending too much of their time and money in providing high motivational lessons. As stated by [3], students agreed that it is convenient to learn vocabulary through mobile apps since it is accessible anywhere and at any time. Hence, they can access the JuJu English Vocabulary apps according to their preferred time and place which makes it easy for them to learn and are able to saves their time. 


\section{Acknowledgment}

This research was supported by Universiti Teknologi Malaysia (UTM) through UTM Encouragement Research Grant (Vot No. Q.J130000.3810.19J64).

\section{References}

[1] Alemi, M., Meghdari, A., \& Ghazisaedy, M. (2015). The impact of social robotics on L2 learners' anxiety and attitude in English vocabulary acquisition. International Journal of Social Robotics, 7(4), 523-535. https://doi.org/10.1007/s12369-015-0286-y

[2] Cavus, N., \& Ibrahim, D. (2019). Learning English using children's stories in mobile devices. British Journal of Educational Technology, 48(2), 625-641. https://doi.org/10.1111/ bjet.12427

[3] Deris, F., \& Shukor, N. (2019). Vocabulary Learning Through Mobile Apps: A Phenomenological Inquiry of Student Acceptance and Desired Apps Features. https://doi.org/10.3991/ ijim.v13i07.10845

[4] Embi, M. A., \& Nordin, N. M. (2013). Mobile learning: Malaysian initiatives and research findings. Malaysia: Centre for Academic Advancement, Universiti Kebangsaan Malaysia, $1-131$.

[5] Eppard, J., Hojeij, Z., Ozdemir-Ayber, P., Rodjan-Helder, M., \& Baroudi, S. (2019). Using mobile learning tools in higher education: A UAE Case. International Journal of Interactive Mobile Technologies (iJIM), 13(11), 51-69. https://doi.org/10.3991/ijim.v13i11.10823

[6] Ironsmith, M., \& Eppler, M. A. (2007). Faculty forum: Mastery learning benefits low-aptitude students. Teaching of Psychology,34(1),28-31.https://doi.org/10.1080/00986280709336645

[7] Katemba, C. V. (2019). Students' vocabulary enhancement at grade 10: A comparative study using CALL \& MALL in Indonesia. CALL-EJ, 20(1), 87-114.

[8] Liyana Ahmad Afip, M. Obaidul Hamid, \& Peter Renshaw. (2019) "Common European framework of reference for languages (CEFR): insights into global policy borrowing in Malaysian higher education." Globalisation, Societies and Education, 17(3), 378-393. https://doi.org/10.1080/14767724.2019.1578195

[9] Maftoon, P., Hamidi, H., \& Sarem, S. N. (2015). The effects of CALL on vocabulary learning: A case of Iranian intermediate EFL learners. BRAIN. Broad Research in Artificial Intelligence and Neuroscience, 3(4), 19-30.

[10] Nisbet, D., \& Austin, D. (2013). Enhancing ESL vocabulary development through the use of mobile technology. Journal of Adult Education, 42(1), 1-7.

[11] Nurul Farehah Mohamad Uri, and Abd Aziz Mohd Salehhuddin. (2018) "Implementation of CEFR in Malaysia: Teachers' awareness and the Challenges." 3L: The Southeast Asian Journal of English Language Studies, 24(3): 168-183. https://doi.org/10.17576/3L-2018-2403-13

[12] Samimi, F., \& Abadi, S. M. M. (2016). The Mediation of Mobile Application in Boosting the Vocabulary Learning of Upper-Intermediate Efl Learners: Advantages and Disadvantages. Modern Journal of Language Teaching Methods, 6(5), 302.

[13] Sato, T., Matsunuma, M., \& Suzuki, A. (2013). Enhancement of automatization through vocabulary learning using CALL: Can prompt language processing lead to better comprehension in L2 reading?. ReCALL, 25(1), 143-158. https://doi.org/10.1017/S0958344012000328

[14] Smith, P. L., \& Ragan, T. J. (2005). Instructional Design. Hoboken: John Wiley \& Sons.

[15] Suwantarathip, O., \& Orawiwatnakul, W. (2015). Using Mobile-Assisted Exercises to Support Students' Vocabulary Skill Development. Turkish Online Journal of Educational Technology-TOJET, 14(1), 163-171. 
[16] Thornton, P., \& Houser, C. (2005). Using mobile phones in English education in Japan. Journal of computer assisted learning, 21(3), 217-228. https://doi. org/10.1111/j.1365-2729.2005.00129.x

[17] Thuy, N. T. T., \& Yukawa, T. (2021). Mobile Devices Applied in Self-Studying English as a Foreign Language Among Non-Native Students in Vietnam and Japan. International Journal of Interactive Mobile Technologies, 16(9). https://doi.org/10.3991/ijim.v15i09.19993

[18] Tozcu, A., \& Coady, J. (2004). Successful learning of frequent vocabulary through CALL also benefits reading comprehension and speed. Computer assisted language learning, 17(5), 473-495. https://doi.org/10.1080/0958822042000319674

[19] Zhang, H., Song, W., \& Burston, J. (2011). Reexamining the effectiveness of vocabulary learning via mobile phones. Turkish Online Journal of Educational Technology-TOJET, 10(3), 203-214.

\section{Authors}

Rooban Arumugam is currently a primary school teacher in Sekolah Kebangsaan Seri Saujana, Kota Tinggi, Johor. He completed his MA in Educational Technology at Universiti Teknologi Malaysia in 2018. The author is specialised in the area of educational technology. He is the Founder of INSPIRE.MY Youtube Channel which provides live tutorials, latest technology informations and news, technology related teaching and learning materials, education application reviews and motivation videos. He has won many awards such as Global Teacher Award, Google Innovator and Google Trainer and Microsoft Certified Educator (email: rooban.arumugam@gmail.com).

Norah Md Noor (Phd) is a Senior Lecturer at Faculty of Social Science and Humanities, and Assoc. Chair (System \& Professional Development) at School of Postgraduate Studies, Universiti Teknologi Malaysia, Skudai, Johor, MALAYSIA (email: norah@utm.my).

Article submitted 2021-09-02. Resubmitted 2021-10-18. Final acceptance 2021-10-22. Final version published as submitted by the authors. 